\title{
SURVEY OF LIVESTOCK PRODUCTION AND MANAGEMENT IN KHYBER PAKHTUNKHWAPROVINCE OF PAKISTAN
}

\author{
Muhammad Ishaq ${ }^{1,2}$, Abdul Hassan², Arshad Farooq² and Lin Xiangsen ${ }^{3, *}$ \\ ${ }^{1}$ College of Economics and Management, Huazhong Agricultural University, Wuhan, China; ${ }^{2}$ Social Sciences \\ Research Institute PARC, Tarnab, Peshawar, Pakistan; ${ }^{3}$ School of Economics Zhongnan University of Economics \\ and Law, Wuhan, China. \\ "Corresponding author's e-mail: xiangsen.lin@znufe.edu.cn
}

\begin{abstract}
This study investigated the existing infrastructure and milk yield performances of different livestock breeds in Khyber Pakhtunkhwa. In this regard 70 livestock farmers were interviewed from different zones of Khyber Pakhtunkhwa including rice-wheat, mixed cropping, low intensity, rainfed and Peri-urban. Results revealed that livestock is the main source of income for $62 \%$ of the respondents followed by (21\%) crop farming. In the study area, $22 \%$ of the famers keep local breed of cattle followed by Sahiwal (18\%), Holstein-Friesian (9\%). Similarly, in the case of buffalo, Nili Ravi is very common and kept by $38 \%$ respondents followed by local breed (22\%). In terms of milk production (liters per day) Sahiwal breed of cow is the most productive ( 9.3 liters per day) followed by Holstein-Friesian (8.7 liters per day), and cross breed (8 liters per day). The area farmers get higher yield of milk from local buffalo ( 7.9 liters per day) followed by Nili Ravi (7.1 liters per day). Results further revealed that large farmers are more efficient in getting milk. Lack of commercial dairy farms, weak infrastructure, lack of financial facilities etc. is some of the constraints hindering productivity of livestock farmers in the study area.
\end{abstract}

Keywords: Milk yield, livestock breeds, farm size, Khyber Pakhtunkhwa

\section{INTRODUCTION}

Like other provinces of Pakistan, in Khyber Pakhtunkhwa livestock also plays a pivotal role by providing food (milk and meat) and a source of income generation. Besides these, livestock serves as store of wealth for the rural peasant, means of transportation and draught power and organic fertilizer for the farm. According to Livestock Census (1996), the province possesses 4.2 million (21\%) cattle, 1.4 million (7\%) buffaloes, 2.8 million (12\%) sheep and 6.8 million (16\%) goats. The province contributed $9 \%$ in milk, $24 \%$ in beef, $15 \%$ in mutton, $20 \%$ in hides, $18 \%$ in skins, $28 \%$ in wool and $17 \%$ in hair production of Pakistan.

In Khyber Pakhtunkhwa, the production and distribution system of livestock and livestock products are traditional and poorly developed. Livestock are reared under sedentary, semi-nomadic and nomadic systems (Sadiq et al., 2003). Livestock farmers belong to small/landless farmers and remain under extensive production system. However, a few large cattle and buffalo farms have also been developed especially in the peri-urban areas.

In the recent past, several attempts have been made to increase livestock production while very little attention has been paid to marketing (Jalil et al., 2009). In many instances, accomplishment in production is not achieved because of poor marketing as farmers usually hesitate in spending additional finances in the adoption of modern production technology unless they are assured of stable market prices.
Plainly, production and marketing are side by side activities i.e., production is considered the first half of any economic activity and marketing is the other half (Lashari et al., 1995). Therefore, it is widely believed that for any successful enterprise, both the production and distribution activities are needed to be performed jointly and efficiently. This in turn not only brings back welfare to the producers but to the consumers as well (Khan, 1999). The livestock sector has been neglected by both the policy makers and researchers (Chaudhry et al., 1999; Burki et al., 2004; Jalil et al., 2009). Consequently, the existing literature on livestock sector is inadequate in Pakistan in general and in Khyber Pakhtunkhwa in particular. There is also lack of reliable information about the livestock population and its products. Therefore, this study was conducted to analyze the existing infrastructure and to estimate the milk yield performances of different livestock breeds across the small, medium and large/commercial livestock farms in Khyber Pakhtunkhwa.

\section{MATERIALS AND METHODS}

The livestock farms were classified into small $(<6$ large ruminants), medium (7-20 large ruminants), and large/commercial (> 20 large ruminants) on the basis of number of livestock holdings. According to the definition of farms 70 livestock farmers were interviewed from different zones of Khyber Pakhtunkhwa including rice-wheat (10 farmers from D.I. Khan), mixed cropping (15 farmers from 
Mardan), low intensity (15 from Kohat), rainfed (10 from D.I. Khan) and Peri-urban (20 from Peshawar), with strict compliance to the devised classification. Farms were selected randomly with the help of livestock department personnel in the respective area. After feeding the data in computer for analysis two respondents were dropped because of outlier effects and therefore the total sample size reduced to 68 . Statistical analyses of the data using frequencies, descriptive statistics including mean and crosstabs were carried out using the Statistical Package for Social Sciences (SPSS) in the light of the objectives.

\section{RESULTS AND DISCUSSION}

Socio-economic characteristics: The livestock farmers of the area were classified into four age groups namely, 25 years or under, 26 to 40,41 to 60 and above 60 (Table 1). In the study area average age of the respondents was 49.7 years and majority of the respondents $(67 \%)$ fell in the age group of 41 to 60 years. It is clear from the data that most of the livestock farmers $(64 \%)$ were illiterate. The results also revealed that most of the respondents $(76 \%)$ preferred and lived in joint family system and therefore $45 \%$ of the households fell in the group of 6 to 10 persons in a family. This indicates that farm families had the potential to supply labor for livestock farming and marketing activities. Data regarding level of involvement of respondents in livestock farming revealed that $79 \%$ of the respondents were fully involved in livestock farming and livestock farming was the main source of income for $62 \%$ of households. In the research area, on average, the respondents were involved in for the last 30 years in livestock keeping.

Table 1. Socioeconomic characteristics of the respondents.

\begin{tabular}{|c|c|c|c|c|}
\hline Types of farm & Small $(n=39)$ & Medium $(n=16)$ & Large $(n=13)$ & All $(n=68)$ \\
\hline Age (years) & 49.3 & 49.8 & 48.5 & 49.7 \\
\hline \multicolumn{5}{|l|}{ Age categories (\%): } \\
\hline 25 or under & 5.2 & n.a & 14.6 & 5.8 \\
\hline $25-40$ & 13.8 & 38.3 & 7.3 & 18.2 \\
\hline $41-60$ & 75.7 & 55.8 & 54.8 & 66.7 \\
\hline above 60 & 5.4 & 6.0 & 23.2 & 9.1 \\
\hline Formal education (years) & 3.7 & 1.9 & 4.7 & 3.4 \\
\hline \multicolumn{5}{|l|}{ Education levels $(\%)$ : } \\
\hline Illiterate & 60.3 & 80.7 & 52.7 & 63.6 \\
\hline Primary & 5.4 & n.a & 7.8 & 4.6 \\
\hline High & 29.1 & 12.9 & 23.5 & 24.2 \\
\hline College & 5.3 & 6.5 & 15.8 & 7.6 \\
\hline Family Size (Nos.) & 10.3 & 14.4 & 17.1 & 12.4 \\
\hline \multicolumn{5}{|l|}{ Family composition (No.): } \\
\hline Male $<15$ years & 2.3 & 3.3 & 4 & 2.8 \\
\hline Female $<15$ years & 1.6 & 3.2 & 4.5 & 2.5 \\
\hline Male $15-60$ years & 3.2 & 3.4 & 3.2 & 3.2 \\
\hline Female $15-60$ years & 2.8 & 3.9 & 4.2 & 3.3 \\
\hline Male $>60$ years & 0.2 & 0.3 & 0.6 & 0.3 \\
\hline Female $>60$ years & 0.2 & 0.3 & 0.6 & 0.3 \\
\hline Living Pattern (\% Joint) & 76.9 & 74.8 & 76.9 & 76.5 \\
\hline \multicolumn{5}{|l|}{ Experience (years): } \\
\hline Farming & 25.4 & 27.1 & 28.2 & 25.6 \\
\hline Livestock & 30.9 & 31.0 & 27.5 & 30.1 \\
\hline Farming (full time \%) & 66.6 & 93.9 & 99.9 & 79.4 \\
\hline \multicolumn{5}{|l|}{ Primary source of income $(\%)$ : } \\
\hline Livestock & 53.9 & 62.5 & 84.7 & 61.8 \\
\hline Crop & 22.9 & 25.1 & 7.5 & 20.6 \\
\hline Government employee & 18.0 & n.a & n.a & 10.3 \\
\hline Livestock related business & n.a & 6.4 & 7.8 & 2.9 \\
\hline Others & 5.2 & 6.0 & n.a & 4.4 \\
\hline \multicolumn{5}{|l|}{ Secondary source of income (\%): } \\
\hline No working off farm & 61.5 & 87.6 & 92.2 & 73.5 \\
\hline Government employee & 23.0 & n.a & n.a & 13.2 \\
\hline Trade (shop etc.) & 5.1 & 6.4 & 7.8 & 5.9 \\
\hline Others & 10.4 & 6.0 & n.a & 7.4 \\
\hline
\end{tabular}

Small $=\leq 6$ large ruminants, medium $=7-20$ large ruminants, large/commercial $=>20$ large ruminants 
Table 2. Agricultural land holdings (acres) of the respondents.

\begin{tabular}{lcccc}
\hline Types of farms & Small & Medium & Large & Total \\
\hline Tenancy status (tenant \%) & $(\mathrm{n}=58.9)$ & $(\mathrm{n}=56.1)$ & $(\mathrm{n}=7.8)$ & $(\mathrm{n}=48.5)$ \\
\hline Operational holdings (acres) & 3.8 & 7.3 & 24.5 & 8.6 \\
Own land (acres) & 2.5 & 4.6 & 17.5 & 5.8 \\
Non-cultivated land(acres) & 0.2 & n.a & n.a & 0.1 \\
Shared in (acres) & 0.8 & 0.1 & n.a & 0.5 \\
Shared out (acres) & n.a & n.a & n.a & n.a \\
Leased in (acres) & 0.8 & 2.6 & 7.0 & 2.4 \\
Leased out (acres) & 0.1 & n.a & n.a & n.a \\
Irrigated (acres) & 3.5 & 5.8 & 24.5 & 8.0 \\
Barani (acres) & 0.3 & 1.6 & n.a & 0.5 \\
\hline
\end{tabular}

Small $=\leq 6$ large ruminants, medium $=7-20$ large ruminants, large/commercial $=>20$ large ruminants

Table 3. Livestock breeds and herd composition.

\begin{tabular}{|c|c|c|c|c|}
\hline Types of Farms & $\begin{array}{c}\text { Small } \\
(n=39)\end{array}$ & $\underset{(n=16)}{\text { Medium }}$ & $\begin{array}{c}\text { Large } \\
(n=13)\end{array}$ & $\begin{array}{c}\text { All } \\
(n=68)\end{array}$ \\
\hline \multicolumn{5}{|c|}{ Breeds present in the area $(\%)$} \\
\hline \multicolumn{5}{|l|}{ Buffalo: } \\
\hline Local & 20.5 & 18.8 & 30.8 & 22.1 \\
\hline Nili-Ravi & 30.8 & 56.3 & 38.5 & 38.2 \\
\hline \multicolumn{5}{|l|}{ Cow: } \\
\hline Local & 17.9 & 25.0 & 30.8 & 22.1 \\
\hline Holstein-Friesian & 10.3 & 6.3 & 7.7 & 8.8 \\
\hline Sahiwal & 10.3 & 31.3 & 23.1 & 17.6 \\
\hline Cross & 5.1 & 6.3 & 0.0 & 4.4 \\
\hline Achai & 10.3 & 6.3 & 0.0 & 7.4 \\
\hline \multicolumn{5}{|c|}{ Herd Composition (Nos) } \\
\hline \multicolumn{5}{|l|}{ Buffalo: } \\
\hline Lactating & 0.6 & 2.4 & 7.6 & 2.4 \\
\hline Dry & 0.2 & 0.9 & 3.8 & 1.1 \\
\hline Pregnant heifer & 0.3 & 0.6 & 2.5 & 0.8 \\
\hline Growing heifer & 0.3 & 0.3 & 3.8 & 0.9 \\
\hline Milk-fed heifer & 0.2 & 0.9 & 6.5 & 1.6 \\
\hline Mature male & n.a & 0.3 & 0.8 & 0.2 \\
\hline Growing male & n.a & n.a & 1.5 & 0.3 \\
\hline Milk-fed male & n.a & n.a & 1.8 & 0.4 \\
\hline Buffalo Population & 1.6 & 5.4 & 28.3 & 7.7 \\
\hline \multicolumn{5}{|l|}{ Cow: } \\
\hline Lactating & 0.5 & 1.6 & 4.5 & 1.5 \\
\hline Dry & 0.2 & 1.6 & 4.9 & 1.4 \\
\hline Pregnant heifer & 0.1 & 0.8 & 2.8 & 0.8 \\
\hline Growing heifer & 0.4 & 1.3 & 4.8 & 1.5 \\
\hline Milk-fed heifer & 0.2 & 0.7 & 3.2 & 0.9 \\
\hline Mature male & 0.1 & 0.8 & 0.3 & 0.3 \\
\hline Growing male & n.a & n.a & 0.8 & 0.1 \\
\hline Milk-fed male & n.a & 0.1 & 2.5 & 0.5 \\
\hline Cow Population & 1.5 & 6.9 & 23.8 & 7.0 \\
\hline Large Ruminants & 3.1 & 12.3 & 52.1 & 14.7 \\
\hline \multicolumn{5}{|l|}{ Others: } \\
\hline Sheep & n.a & 0.4 & 0.5 & 0.2 \\
\hline Goat & 5.4 & 12.1 & 3.3 & 6.6 \\
\hline Donkey & 0.1 & 0.1 & 0.2 & 0.1 \\
\hline Horse & n.a & 0.8 & n.a & 0.2 \\
\hline Total Herd & 8.6 & 25.7 & 56.1 & 21.8 \\
\hline
\end{tabular}

Small $=\leq 6$ large ruminants, medium $=7-20$ large ruminants, large/commercial $=>20$ large ruminants
Farm characteristics: In the Thakur et al., 1990). It was observed during the field survey that some of the livestock farmers owned 17.5 acres which could create an upward bias in the estimates of farm size. While on average, the respondents operated 8.6 acres of land.

Livestock breeds and herd composition: Afzal and Naqvi (2004) described different breeds of cattle and buffalo of Pakistan along with their characteristics. In the study area, Nili-Ravi breed of buffalo is very common and kept by $38 \%$ of the respondents while only $22.1 \%$ of the respondents kept local breed (Table 3). In case of cow, local breed is very common among the respondents and accounted for $22.1 \%$ of the total herd, followed by Sahiwal (17.6\%), HolsteinFriesian (8.8\%), Achai (7.4\%) and cross breed (4.4\%).

Herd composition (Table 3 ) in the study area show that number of unproductive animals (dry, pregnant, growing and milk fed heifer and male) were more than that of productive animals (lactating). In case of buffalo, on an average, the respondents kept 2.4 lactating, 1.1 dry, 0.8 pregnant, 0.9 growing heifer, 1.6 milk-fed heifer, 0.2 mature male, 0.3 growing male and 0.4 milk-fed male. Similarly, in case of cow, on an average the herd comprised of 1.5 lactating, 1.4 dry, 0.8 pregnant, 1.5 growing heifer, 0.9 milk-fed heifer, 0.3 mature male, 0.1 growing male and 0.5 milk-fed male. The number of lactating animals also varied across the small, medium and large farms in the area. In addition to buffalo and cow, some of the respondents also kept other animals in their herd like sheep, goat, donkey and horse.

Like other natural resources, nature has gifted the country with rich livestock genetic resources. For instance, Pakistani buffaloes are riverine type; Nili-Ravi and Kundi are the two main breeds. Nili-Ravi is considered the best dairy buffalobreed of the world (Shah, 1991). Bhutto et al., (1993), Naqvi and Wahid (1975) identified ten distinct breeds of cattle in Pakistan. In the past, when agriculture was not mechanized, cattle were kept mainly for draught purpose but now these cattle are being kept for dairy and meat purposes. In this regard, to get high milk yielding, local breed of cattle are also being crossed with exotic breeds (Khan, 1994). However, at 
present, livestock are kept mainly to meet milk and meat demand and also for draught power in some of the areas.

According to Iqbal and Ahmad (1990), breeds of large ruminants are famous either for milk or draught purposes and there is hardly any breed for beef production in Pakistan. In this way, milk production is considered the main purpose of raising livestock in the country.

Iqbal and Ahmad (1990) pointed out that livestock population in Pakistan comprises mainly of unproductive and low productive animals that share in feed and management with the productive stock. This results in decreased national average production of milk and meat. In addition, composition of national herd is also not economical. This shows it almost impossible to meet the rising demand for livestock products at its present level of productivity per animal.

\section{Farm Management:}

Age at first calving: In the study area, the average age at first calving was 31.2 months (Table 4) for local buffalo and 32.4 months in case of Nili-Ravi. This age was minimal for local breeds of cow (24.0 months) as this breed has adapted very well to the local environment followed by Sahiwal (34.8 months), Holstein-Friesian, cross bred (39.6 months each), and Achai (38.4 months).

The time after birth till first calving of heifer is expensive one as in this period a considerable capital cost is incurred on feed, housing, and health care. According to Heinrichs (1993), expenses during this period constitute 15 to $20 \%$ of the total expenses related to milk production. According to Gardner et al. (1988), Radcliff et al. (2000), Van Amburgh et al. (1998), this period of first calving may either be reduced through combination of increasing pre-pubertal average daily gain and decreasing age at breeding or by reducing age at breeding alone (Ettema and Santos 2004; Lin et al., 1986). Reduction in age at first calving may minimize the cost (Tozer and Heinrichs, 2001) and improve the profitability of the farm by increasing lifetime milk production and milk production per year (Lin et al., 1988). Calving Interval

In the study area (Table 4) average calving interval was in the range of eleven months. The calving interval was the shortest for local (8.2 months) and cross bred (9.8 months) cows. While for the rest of animals the calving interval was nearly eleven months.

Profitability of a dairy farm is determined by milk yield and reproductive performance of a dairy herd. In modern dairies, it is generally practiced to breed cows early in order to establish optimum calving interval of 12 to 13 months (Arbel et al., 2001). Weller and Folman (1990) stated that late conception reduces profitability in the cases when the value of a calf is high. While Heimann (1984) advocated prolonged calving intervals in case of high yielding cows with good persistency. In nutshell, it is argued that calving interval is determined by milk production level and continuity in lactation period (Arbel et al., 2001). Milk frequency and milk yield.

Table 4. Dairy farm characteristics and management.

\begin{tabular}{|c|c|c|c|c|c|}
\hline & Types of farm & $\begin{array}{c}\text { Small } \\
(n=39)\end{array}$ & $\begin{array}{c}\text { Med. } \\
(n=16)\end{array}$ & $\begin{array}{c}\text { Large } \\
(n=13)\end{array}$ & $\begin{array}{c}\text { All } \\
(n=68)\end{array}$ \\
\hline \multirow{2}{*}{ 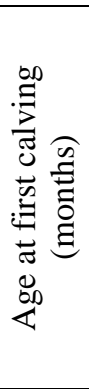 } & $\begin{array}{l}\text { Species and Breed } \\
\text { Buffalo: } \\
\text { Local } \\
\text { Nili-Ravi }\end{array}$ & $\begin{array}{l}27.6 \\
30.0\end{array}$ & $\begin{array}{l}45.6 \\
34.8 \\
\end{array}$ & $\begin{array}{l}28.8 \\
34.8 \\
\end{array}$ & $\begin{array}{l}31.2 \\
32.4\end{array}$ \\
\hline & $\begin{array}{l}\text { Cow: } \\
\text { Local } \\
\text { Holstein-Friesian } \\
\text { Sahiwal } \\
\text { Cross } \\
\text { Achai }\end{array}$ & $\begin{array}{l}16.8 \\
39.6 \\
40.8 \\
36.0 \\
33.6\end{array}$ & $\begin{array}{l}36.0 \\
36.0 \\
28.8 \\
48.0 \\
60.0\end{array}$ & $\begin{array}{l}27.6 \\
48.0 \\
36.0\end{array}$ & $\begin{array}{l}24.0 \\
39.6 \\
34.8 \\
39.6 \\
38.4\end{array}$ \\
\hline \multirow{2}{*}{ 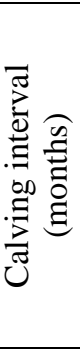 } & $\begin{array}{l}\text { Buffalo: } \\
\text { Local } \\
\text { Nili-Ravi } \\
\end{array}$ & $\begin{array}{l}10.5 \\
12.3 \\
\end{array}$ & $\begin{array}{c}7.7 \\
11.6 \\
\end{array}$ & $\begin{array}{l}11.3 \\
10.0 \\
\end{array}$ & $\begin{array}{l}10.1 \\
11.6 \\
\end{array}$ \\
\hline & $\begin{array}{l}\text { Cow: } \\
\text { Local } \\
\text { Holstein-Friesian } \\
\text { Sahiwal } \\
\text { Crossbred } \\
\text { Achai } \\
\end{array}$ & $\begin{array}{c}6.2 \\
11.6 \\
11.3 \\
9.8 \\
10.3 \\
\end{array}$ & $\begin{array}{l}11.3 \\
11.0 \\
11.1 \\
10.0 \\
14.0\end{array}$ & $\begin{array}{c}8.5 \\
8.0 \\
10.7 \\
\text { n.a. } \\
\text { n.a. }\end{array}$ & $\begin{array}{c}8.2 \\
10.9 \\
11.0 \\
9.8 \\
11.0 \\
\end{array}$ \\
\hline \multirow{2}{*}{ 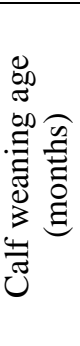 } & $\begin{array}{l}\text { Buffalo: } \\
\text { Local } \\
\text { Nili-Ravi }\end{array}$ & $\begin{array}{l}4.9 \\
4.2 \\
\end{array}$ & $\begin{array}{l}2.8 \\
5.0\end{array}$ & $\begin{array}{l}2.8 \\
4.7 \\
\end{array}$ & \\
\hline & $\begin{array}{l}\text { Cow: } \\
\text { Local } \\
\text { Holstein-Friesian } \\
\text { Sahiwal } \\
\text { Cross } \\
\text { Achai }\end{array}$ & $\begin{array}{l}6.2 \\
5.5 \\
5.5 \\
5.5 \\
3.8\end{array}$ & $\begin{array}{c}5.5 \\
12.0 \\
6.6 \\
4.0 \\
5.0\end{array}$ & $\begin{array}{l}5.3 \\
4.0 \\
6.2 \\
\text { n.a. } \\
\text { n.a. }\end{array}$ & $\begin{array}{l}5.9 \\
6.3 \\
6.1 \\
5.0 \\
4.1\end{array}$ \\
\hline \multirow{2}{*}{ 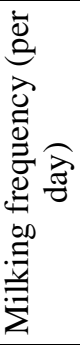 } & $\begin{array}{l}\text { Buffalo: } \\
\text { Local } \\
\text { Nili-Ravi } \\
\end{array}$ & $\begin{array}{l}1.8 \\
1.8\end{array}$ & $\begin{array}{l}2.0 \\
2.0 \\
\end{array}$ & $\begin{array}{l}2.0 \\
2.0\end{array}$ & $\begin{array}{l}1.9 \\
1.9\end{array}$ \\
\hline & $\begin{array}{l}\text { Cow: } \\
\text { Local } \\
\text { Holstein-Friesian } \\
\text { Sahiwal } \\
\text { Crossbred } \\
\text { Achai } \\
\end{array}$ & $\begin{array}{l}1.4 \\
2.3 \\
2.0 \\
2.0 \\
1.5\end{array}$ & $\begin{array}{l}1.8 \\
2.0 \\
2.0 \\
2.0 \\
2.0\end{array}$ & $\begin{array}{c}2.0 \\
2.0 \\
2.0 \\
\text { n.a. } \\
\text { n.a. }\end{array}$ & $\begin{array}{l}1.7 \\
2.2 \\
2.0 \\
2.0 \\
1.6\end{array}$ \\
\hline \multirow{2}{*}{ 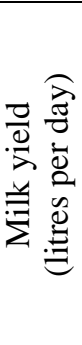 } & $\begin{array}{l}\text { Buffalo: } \\
\text { Local } \\
\text { Nili- Ravi }\end{array}$ & $\begin{array}{l}5.6 \\
5.3 \\
\end{array}$ & $\begin{array}{l}9.7 \\
7.7 \\
\end{array}$ & $\begin{array}{l}11.0 \\
10.4 \\
\end{array}$ & $\begin{array}{l}7.9 \\
7.1 \\
\end{array}$ \\
\hline & $\begin{array}{l}\text { Cow: } \\
\text { Local } \\
\text { Holstein-Friesian } \\
\text { Sahiwal } \\
\text { Crossbred } \\
\text { Achai }\end{array}$ & $\begin{array}{l}1.8 \\
8.0 \\
9.0 \\
6.0 \\
1.8\end{array}$ & $\begin{array}{c}4.5 \\
10.0 \\
7.8 \\
12.0 \\
3.0\end{array}$ & $\begin{array}{c}5.5 \\
10.0 \\
12.0 \\
\text { n.a. } \\
\text { n.a. }\end{array}$ & $\begin{array}{l}3.5 \\
8.7 \\
9.3 \\
8.0 \\
2.0\end{array}$ \\
\hline
\end{tabular}

Small $=\leq 6$ large ruminants, medium $=7-20$ large ruminants, large/commercial $=>20$ large ruminants

In the study area (Table 4), livestock farmers get milk almost twice a day from both the lactating cows and buffaloes. 
However, in case of Holstein-Friesian, the frequency was higher than two.

Table 5. Milk yield (litres per day) across different livestock breeds

\begin{tabular}{|c|c|c|c|c|c|}
\hline $\begin{array}{l}\text { Types of } \\
\text { farm }\end{array}$ & & $\begin{array}{c}\text { Small } \\
(n=39)\end{array}$ & $\underset{(n=16)}{\text { Medium }}$ & $\begin{array}{l}\text { Large } \\
(\mathrm{n}=13)\end{array}$ & $\underset{\substack{\text { All } \\
(\mathrm{n}=68)}}{ }$ \\
\hline \multicolumn{2}{|l|}{$\begin{array}{l}\text { Breed } \\
\text { Buffalo: }\end{array}$} & \multicolumn{3}{|c|}{ Quarter } & \\
\hline \multirow{4}{*}{ Local } & $1^{\text {st }}$ & 8.4 & 11.3 & 11.0 & 9.0 \\
\hline & $2^{\text {nd }}$ & 6.7 & 8.7 & 8.0 & 6.9 \\
\hline & & 4.6 & 7.0 & 5.0 & 4.8 \\
\hline & Beyond $3^{\text {rd }}$ & 2.7 & 5.3 & 3.5 & 2.9 \\
\hline \multirow{4}{*}{ Nili Ravi } & \begin{tabular}{|l|l|l} 
st \\
\end{tabular} & 9.3 & 9.7 & 10.3 & 9.6 \\
\hline & $2^{\text {nd }}$ & 7.6 & 7.9 & 7.5 & 7.7 \\
\hline & $3^{\text {rd }}$ & 5.7 & 6.3 & 4.7 & 5.8 \\
\hline & Beyond $3^{\text {rd }}$ & 3.4 & 3.6 & 3.5 & 3.5 \\
\hline \multicolumn{6}{|l|}{ Cow: } \\
\hline \multirow{4}{*}{ Local } & $1^{\text {st }}$ & 3.9 & 5.0 & 9.9 & 5.8 \\
\hline & $2^{\text {nd }}$ & 3.2 & 3.3 & 7.7 & 4.3 \\
\hline & $3^{\text {rd }}$ & 2.0 & 1.6 & 5.0 & 2.6 \\
\hline & Beyond $3^{\text {rd }}$ & 1.6 & 1.8 & 4.0 & 2.2 \\
\hline \multirow{4}{*}{$\begin{array}{l}\text { Holstein- } \\
\text { Friesian }\end{array}$} & $1^{\text {st }}$ & 9.0 & 10.0 & 13.0 & 9.8 \\
\hline & $2^{\text {nd }}$ & 7.1 & 7.0 & 7.5 & 7.2 \\
\hline & $3^{\text {rd }}$ & 5.8 & 5.0 & 6.5 & 5.8 \\
\hline & Beyond $3^{\text {rd }}$ & 4.0 & 2.0 & n.a. & 3.3 \\
\hline \multirow{4}{*}{ Sahiwal } & $1^{\text {st }}$ & 11.0 & 11.6 & 13.3 & 11.8 \\
\hline & $2^{\text {nd }}$ & 9.5 & 9.0 & 11.0 & 9.7 \\
\hline & $3^{\text {rd }}$ & 8.5 & 5.8 & 6.3 & 6.8 \\
\hline & Beyond $3^{\text {rd }}$ & 7.0 & 4.0 & 6.5 & 5.8 \\
\hline \multirow{4}{*}{ Crossbred } & $1^{\text {st }}$ & 11.3 & 12.0 & n.a. & 11.5 \\
\hline & $2^{\text {nd }}$ & 10.8 & 12.0 & n.a. & 11.2 \\
\hline & $3^{\text {rd }}$ & 7.3 & 12.0 & n.a. & 8.8 \\
\hline & Beyond $3^{\text {rd }}$ & 5.0 & 5.0 & n.a. & 5.0 \\
\hline \multirow{4}{*}{ Achai } & $1^{\text {st }}$ & 4.0 & 4.0 & n.a. & 4.0 \\
\hline & $2^{\text {nd }}$ & 3.2 & 3.0 & n.a. & 3.1 \\
\hline & $3^{\text {rd }}$ & 3.2 & 2.0 & n.a. & 2.9 \\
\hline & Beyond $3^{\text {rd }}$ & 4.0 & n.a. & n.a. & 4.0 \\
\hline
\end{tabular}

Small $=\leq 6$ large ruminants, medium $=7-20$ large ruminants, large/commercial $=>20$ large ruminants

In terms of milk production (liters per day), in the study area it was noticed that the local breed of buffalo is high yielding (7.9 liters per day) rather than Nili Ravi (7.1 liters per day). While in case of cow, Sahiwal breed is the most productive with 9.3 liters per day followed by Holstein-Friesian (8.7 liters per day) cross bred (8.0 liters per day), local (3.5liters per day) and Achai cattle (2.0liters per day). Large farmers were more efficient in getting milk from Sahiwal (12.0 liters per day), followed by Holstein-Friesian (10.0 liters per day) and local breed (5.5liters per day) of cattle, while in case of cross bred cows medium farmers received higher yield (12.00 liters per day).
It is believed that milk yield increases with more frequent milking (Henderson et al., 1983; Hillerton et al., 1990; Ouweltjes, 1998; Wilde et al., 1988; Wilde et al., 1987) and milking three times a day increases milk yield as compared to two times a day. According to Stelwagen and Lacy-Hulbert (1996) "longer intervals between milking have a negative effect on milk production and milking only once a day has been shown to increase the somatic cell count in milk". Poole (1982), DePeters et al. (1985), Ouweltjes (1998) and Erdman et al. (1995) found that a longer time between milking results in lower milk yield, especially in the cases when production level is high. Contrarily, researchers like Allen et al. (1986), Szuchs et al. (1986) and Barnes et al. (1990) reported that concentrations of milk components decrease with milking while Amos et al. (1985) and DePeters et al. (1985) observed no significant change and suggest that increased milk frequency is beneficial for udder health. Persistency in milk yield of a cow is considered an important factor for total milk yield during lactation. Milking animals that give the same yields (at the peak) throughout the lactation period had significantly different total yield. According to Grossman et al. (1999) "a typical lactation curve can be described as increasing from initial yield at calving to maximum peak yield, a plateau maintaining peak yield, and a decrease from peak yield to the end of the lactation". Milking animals maintaining peak yield for a longer time are considered persistent. In other words, animals with a flatter lactation curve are more persistent than animals having rapidly downward sloping curve after reaching maximum (Grossman, et al., 1999).

Milk production and disposal: According to Burki et al. (2004), about $15 \%$ of the milk is being wasted due to noncommercial milk production system and non-availability of proper facilities like cooling and storage mechanism. Majority (98\%) of the milk produced in the rural areas (Table 6) is consumed by the households as raw milk in the form of boiled milk and various traditional value added products like butter oil (desi ghee), yogurt, lassi (drink prepared from fermented milk after removing cream), and cheese etc. Surplus milk is informally marketed in the village through Gawalla (local milkman) or sold to the sweet makers in the cities. About $97 \%$ of the milk which are mainly loose milk and consumed in the villages and or sold in the cities through "Gawallas" without any hygienic and quality standards. Therefore, Pakistan Dairy Development Company (2006) reported that livestock farmers are not making progress in economic terms and the sector contribution to the National economy is not significant despite the huge milk potential.

Livestock health: In the study area, vaccination cost was high (Rs. 161.67 per annum) for large herds of cows followed by small (Rs. 115.83) while lower (Rs. 104) for medium cow herds with a mean vaccination cost of Rs. 128 per annum (Table 7). Similarly, the per annum treatment cost for cow 
was Rs. 1,780 for large herds, Rs. 1,350for medium and Rs. 941.54 for small herds. The per annum de-worming cost was Rs. 357.50 for large cow herds, Rs. 200.71 for medium and Rs. 112.5 for small cow herds. Furthermore, the vaccination cost is high (Rs. 508.33 per annum) for small herds of buffalo followed by medium (Rs. 227 per annum) while lower (Rs. 147) for large buffalo herds with a mean vaccination cost of Rs. 289.72 per annum. Similarly, the treatment cost for buffalo is Rs. 1396 per annum for large herds, Rs. 1160 per annum for medium and Rs.1142.31 per annum for small buffalo herds. The table further reveals that the de-worming cost is high (Rs.332.86 per annum) for small herds of buffalo followed by large (Rs. 315) while lower (Rs.238) for medium buffalo herds with a mean worming cost of Rs. 298.25 per annum.

Good animal health is a central segment for a profitable dairy enterprise to obtain maximum production. Precise records, comprising information on medications, vaccinations,

\section{Feed Management}

Feed consumption: Livestock feeding is of crucial importance in livestock management. In the study area (Table ?), green fodder is not available throughout the year. To meet the nutritional requirements of livestock a variety of fodders and feeds resources are utilized. Green fodder and other crops and crop residues form the bulk of feed for livestock. Concentrates are fed mostly to lactating animals for higher milk yield. In addition, dry fodder is fed to animals in green fodder shortage period.

In the study area, wheat, oat, berseem, shaftal, maize and sorghum are grown and fed to livestock. Dry fodders include mainly wheat straw (bhosa) and maize stalk. In the study area, maize is grown specifically for fodder purposes and used either as a green fodder or carried over as dry stalks and used during fodder scarcity period. Wheat straw is also fed during green fodder shortage period, mostly mixed with chokar (bran). In addition, concentrates (oil seed cake, choker) and

Table 6. Milk production and disposal (Kg per day) during summer and winter

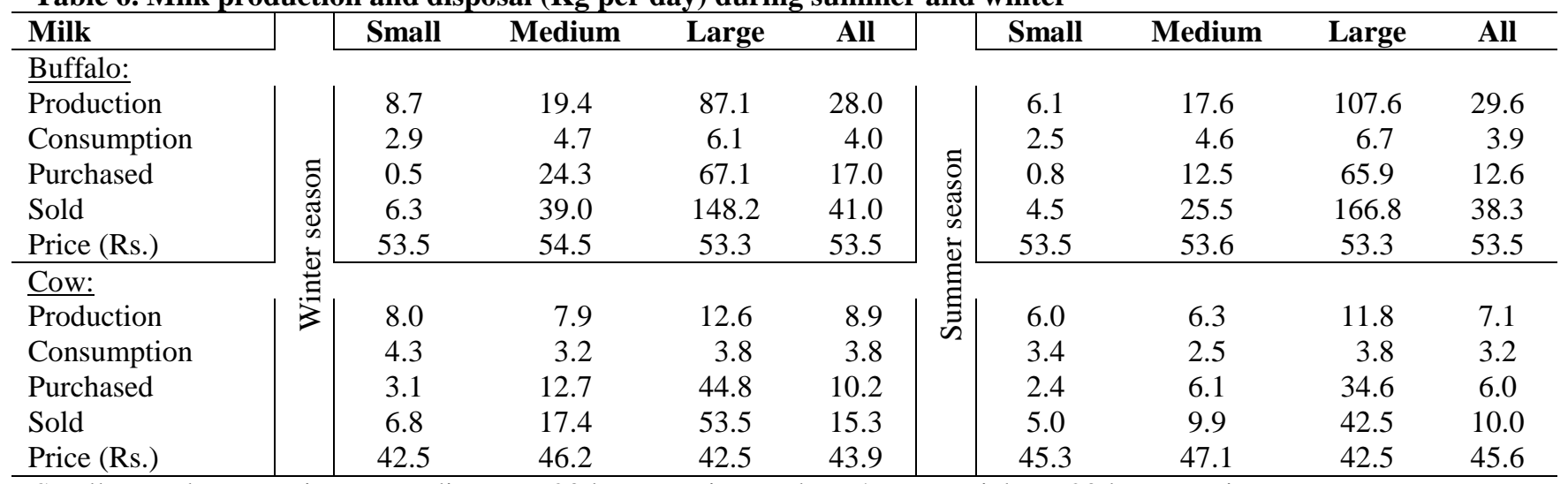

Small $=\leq 6$ large ruminants, medium $=7-20$ large ruminants, large/commercial $=>20$ large ruminants

Table 7. Medical expenses (Rs/annum).

\begin{tabular}{|c|c|c|c|c|}
\hline \multirow{2}{*}{$\begin{array}{l}\text { Types of farms } \\
\text { Cost (Rs/Annum) }\end{array}$} & Small $(n=39)$ & Medium (n=16) & Large $(n=13)$ & All \\
\hline & \multicolumn{4}{|c|}{ Cow } \\
\hline Vaccination & 115.83 & 104.00 & 161.67 & 128.53 \\
\hline Treatment & 941.54 & 1350.00 & 1780.00 & 1206.36 \\
\hline \multirow[t]{2}{*}{ Deworming } & 112.50 & 200.71 & 357.50 & 235.29 \\
\hline & \multicolumn{4}{|c|}{ Buffalo } \\
\hline Vaccination & 508.33 & 227.00 & 147.14 & 289.72 \\
\hline Treatment & 1142.31 & 1160.00 & 1396.00 & 1216.88 \\
\hline Deworming & 332.86 & 238.33 & 315.00 & 298.25 \\
\hline
\end{tabular}

Small $=\leq 6$ large ruminants, medium $=7-20$ large ruminants, large/commercial $=>20$ large ruminants

injuries, production, breeding and culling etc., should be kept on each animal which can be used to plan a herd health program. Furthermore, geographic region, type of cattle operation, frequency of introducing new cattle, post vaccination problems and export may also be required before starting a vaccination program (Pennington and Powell, n.d.).
Gur (raw sugar), spices oil/ghee and salts are also fed to livestock.

In dairy animals, with the onset of lactation, feed requirements increase. According to Bell (1995), this increase in feed requirements is partially met through voluntary feed 
Table 8. Livestock feeding calendar.

\begin{tabular}{|c|c|c|c|c|c|c|c|c|c|c|c|c|}
\hline & Jan & Feb & Mar & Apr & May & Jun & Jul & Aug & Sep & Oct & Nov & Dec \\
\hline \multicolumn{13}{|l|}{ Green Fodder: } \\
\hline \multicolumn{13}{|l|}{$\begin{array}{l}\text { Shaftal/Barseem }(T . \\
\text { resupinatum })\end{array}$} \\
\hline \multicolumn{13}{|l|}{ Maize (Zea mays) } \\
\hline \multicolumn{13}{|l|}{$\begin{array}{l}\begin{array}{l}\text { Sorgham } \\
\text { (Sorghum bicolor) }\end{array} \\
\end{array}$} \\
\hline \multicolumn{13}{|l|}{$\begin{array}{l}\text { Millet } \\
\text { Pennisetum glaucum }\end{array}$} \\
\hline \multicolumn{13}{|l|}{\begin{tabular}{|l} 
Barley \\
(Hordeum vulgare)
\end{tabular}} \\
\hline \multicolumn{13}{|l|}{$\begin{array}{l}\text { Wheat } \\
\text { (Triticum aestivum) }\end{array}$} \\
\hline \multirow{2}{*}{\multicolumn{13}{|c|}{$\begin{array}{l}\text { Sugarcane tops } \\
\text { Dry Fodder: }\end{array}$}} \\
\hline & & & & & & & & & & & & \\
\hline \multicolumn{13}{|l|}{ Wheat } \\
\hline \multicolumn{13}{|l|}{ Maize } \\
\hline \multicolumn{13}{|l|}{ Concentrates: } \\
\hline \multicolumn{13}{|l|}{ Oil Seed Cake } \\
\hline \multicolumn{13}{|l|}{ Chokar(Bran) } \\
\hline \multicolumn{13}{|l|}{$\begin{array}{l}\text { Vanda (Concentrate } \\
\text { mixture) }\end{array}$} \\
\hline \multicolumn{13}{|l|}{ Supplementary Feed: } \\
\hline \multicolumn{13}{|l|}{ Oil/Ghee } \\
\hline Salts (minerals) & & & & & & & & & & & & \\
\hline
\end{tabular}

intake and to a certain extent by a range of metabolic variation. Readily access to water and nutrients is considered a prerequisite for higher yield in milking animals. This increase in feed intake results in a higher milk yield (Broster et al., 1985; Agenas et al., 2002).

Feeding calendar: In the study area, as mentioned earlier, animal feeds consist of wider combination of green fodders, dry roughages and concentrate supplements. In the province of Khyber Pakhtunkhwa, berseem, Trifolium alexandernum is the major green fodder (Table 8) and feed along with dry feeds from last week of December till mid of May. Sugarcane or sugarcane tops are available as livestock feed in central Khyber Pakhtunkhwa from January-March. Maize and sorghum are fed from June to September as green fodder. In addition to these, early sown wheat (as fodder) is also fed to livestock in some of the areas during January to February. Both wheat straw (bhosa) and maize stalk constitute the bulk of the dry fodder and feed to the animals during green fodder scarcity period (Juneto July and November-December). Concentrate feeds (oil seed cake, choker and vanda) are fed throughout the years only to lactating animals whereas, gur (raw sugar), and oil/ghee are fed twice a year each in summer and winter to livestock.

Conclusion: This study aims to analyze the existing infrastructure and estimate milk yield performances of different livestock breeds across the small, medium, and large/commercial farms in different agro-ecological zones in the province of Khyber Pakhtunkhwa. The study finds that livestock farms are run by the age group of 41-60 years and most of the respondents are illiterate. Livestock keeping is the main source of income followed by crop farming. Number of dry animals is more in a farm than that of milking animals. In the study area, local breeds of cattle and buffalos are very common. In terms of milk production (liters per day) Sahiwal breed of cow and local breed of buffalo are the most productive. Average age at first calving is minimal for local breed of cow and Kundi breed of buffalo. The claving interval is about eleven months for both cattle and buffalo; minimal for cross breed of cow and Kundi breed of buffalo. Base on the findings of the study it is concluded that the dairy sector is plagued by a number of problems which include lack of commercial dairy farms, low productivity due to poor nutrition, a weak infrastructure, lack of financial facilities, and the ready availability of raw milk to a poor and uneducated population. Although Pakistan ranks fourth among the five leading milk producing countries in the world, still its yield per animal is only one-fifth of that of Western Europe. Therefore, a crash program is needed to address these issues and increase the yield per animal till its potential level.

\section{REFERENCES}

Afzal, M. and A. Naqvi. 2004. Livestock resources of Pakistan: Present status and future trends. Q. Sci. Vis., 9 (1-2 (Jul - Dec, 2003) and 3-4 (Jan - Jun, 2004)):1-14. 
Agenas, S.D. and K. Holtenius. 2002. Changes in metabolism and milk production during and after feed deprivation in primiparous cows selected for different milk fat content. In: Regulation of milk production in cows selected for different milk fat content with special reference to transition. Acta Universitatis Agriculturae Scandinavica. Uppsala. Sweden: Swedish University of Agricultural Sciences.

Allen, D., E. DePeters, and R. Laben. 1986. Three times a day milking: effects on milk production, reproductive efficiency, and udder health. J. Dairy Sci. 69:1441-1446.

Amos, H., T. Kiser and M. Loewenstein. 1985. Influence of milking frequency on productive and reproductive efficiencies of dairy cows. J Dairy Sci. 68:732-739.

Arbel, R., Y. Bigun, E. Ezra, H. Sturman and D. Hojman. 2001. The effect of extended calving intervals in high lactating cows on milk production and profitability. $\mathbf{J}$ Dairy Sci. 84:600-608.

Barnes, M., R. Pearson, and A. Lukes-Wilson. 1990. Effects of milking frequency and selection for milk yield on productive efficiency of Holstein cows. J. Dairy Sci. 73:1603-1611.

Bell, A. 1995. Regulation of organic nutrient metabolism during transition from late pregnancy to early lactation. J. Anim. Sci. 73:2804-2819.

Bhutto, M.A., M. Khan and G. Ahmad. 1993. Livestock breeds of Pakistan. Ministry of Food, Agriculture and Livestock, Government of Pakistan.

Broster, W., J. Sutton, J. Bines, V. Broster, T. Smith and J. Siviter. 1985. The influence of plain of nutrition and diet composition on the performance of dairy cows. J. Agri. Sci. 104:535-557.

Burki, M., M.A. Khan and F. Bari. 2004. The state of Pakistan's dairy sector: an assessment. Pak. Dev. Rev.43:149-174.

Chaudhry, M.G., A. Munir and G.M. Chaudhry. 1999. Growth of livestock production in Pakistan: An analysis. Pak. Dev. Rev. 38:605-614.

DePeters, E., N. Smith and J. Acedo-Rico. 1985. Three or two times daily milking of older cows and first lactation cows for entire lactations. J. Dairy Sci. 68:123-132.

Erdman, R. and M. Varner. 1995. Fixed yield responses to increased milking frequency. J. Dairy Sci. 78:1199-1203.

Ettema, J.F. and J.E. Santos. 2004. Impact of age at calving on lactation, reproduction, health, and income in firstparity Holsteins on commercial farms. J. Dairy Sci. 87:2730-2742.

Gardner, R.W., L.W. Smith and A.R. Park. 1988. Feeding and management of dairy heifers for optimal lifetime productivity. J. Dairy Sci. 71:996-999.

GoP. 2013. Economic Survey of Pakistan 2012-13. Islamabad: Economic Advisor's Wing, Ministry of Finance, Islamabad, Pakistan.
Grossman, M., S. Hartz and W. Koops. 1999. Persistency of lactation yield: a novel approach. J. Dairy Sci. 82:21922197.

Heimann, M. 1984. Results of an integrative computer program of fertility and production data from ai cattle population. Proceedings of the Tenth International Congress on Animal Reproduction and Artificial Insemination, 1; Urbana, IL. USA.

Heinrichs, A.J. 1993. Raising dairy replacements to meet the needs of the $21^{\text {st }}$ century. J. Dairy Sci. 76:3179-3187.

Henderson, A.J., D. Blatchford and M. Peaker. 1983. The effect of milking thrice instead of twice daily on milk secretion in the goat. Quart. J. Exp. Physiol. 68:645.

Hillerton, J., C.H. Knight, A. Turvey, S.D. Wheatley and C. Wilde. 1990. Milk yield and mammary function in dairy cows milked four times daily. J. Dairy Sci. 57:285-294.

Iqbal, M. and M. Ahmad. 1990. An assessment of livestock production potential in Pakistan: Implications for livestock sector policy. Pak. Dev. Rev. 38:615-628.

Jalil, H., H.U. Rehman, M.H. Sial and S.S. Hussain. 2009. Analysis of milk production system in peri-urban areas of Lahore (Pakistan)-A case study. Pak. Econ. Soc. Rev.47:229-242.

Khan, M. 1999. Economics of milk production and marketing in the development of Pakistan with special reference to Peshawar district. Ph.D. Thesis, University of Wales, Aberystwyth, UK.

Khan, U. 1994. Genetic improvement of native cattle through crossbreeding and introduction of exotic dairy cattle in Pakistan. Pakistan Science Foundation, Islamabad, Pakistan.

Lashari, M.I., A.M. Manganhar and M. Shar. 1995. Factors affecting chilies production and marketing in Sindh. Agricultural Economics Research Unit (AERU), A.R.I. Tando Jam, Sindh, Pakistan.

Lin, C.Y., A.J. McAllister, T.R. Batra, A.J. Lee, G.L. Roy and J.A. Vesely. 1988. Effects of early and late breeding of heifers on multiple lactation performance of dairy cows. 71:2735-2743.

Lin, C.Y., A.J. McAllister, T.R. Batra, A.J. Lee, G.L. Roy and J.A. Vesely. 1986. Production and reproduction of early and late bred dairy heifers. Journal name???69:760-768.

Maureithi, L., B. Makau and I. Ahmad. 1992. Biotechnology and farm size in Kenya Biotechnology: a hope or a threat? Basigstorke UK: McMillan press Ltd.

Naqvi, A. and S. Jafar. 1989. Dairy cattle breeding in Pakistan. Pakistan Agricultural Research Council, Islamabad, Pakistan.

Ouweltjes, W. 1998. The relationship between milk yield and milking interval in dairy cows. Liv. Prod Sci. 56:193201.

Poole, D. 1982. The effects of milking cows three times daily. Anim. Prod. 34:197-201. 
Radcliff, R.P., M.J. VandeHaar, L.T. Chapin, T.E. Pilbeam, D.K. Beede and E.P. Stanisiewski. 2000. Effects of diet and injection of bovine somatotropin on prepubertal growth and first-lactation milk yields of Holstein Cows. J. Dairy Sci. 83:23-29.

Sadiq, G., M. Ishaq and S.H. Saddozai. 2003. Estimation of cost and revenue and analysis of the different factors affecting livestock production. Sarhad J. Agric. 19:579584.

Shah, S.K. 1991. Buffaloes of Pakistan. Pakistan Agricultural Research Council, Islamabad, Pakistan.

Stelwagen, K. and J. Lacy-Hulbert. 1996. Effect of milking frequency on milk somatic cell count characteristics and mammary secretory cell damage in cows. AJVR 57:902905.

Szuchs, E., I. Acs, K. Ugri, M. Sas, I. Torok and E. Fodor. 1986. Milking 3 times a day in a herd with high milk yield. Dairy Sci. Abst. 48:360.

Thakur, D., T. Moorti and H. Sharma. 1990. Resource use farm size and returns to scale on tribal farm of Himachal Pardesh. Agri. Situ. India 44:885-891.
Tozer, P.R. and A.J. Heinrichs. 2001. What affects the costs of raising replacement dairy heifers: a multiplecomponent analysis? J. Dairy Sci. 84:1836-1844.

Van Amburgh, M.E., D.M. Galton, D.E. Bauman, R.W. Everett, D.G. Fox and L.E. Chase. 1998. Effects of three prepubertal body growth rates on performance of Holstein heifers during first lactation. J. Dairy Sci. 81:527-538.

Wahid, A. 1975. Livestock resources of Pakistan: Lohani Cattle. Karachi: University of Karachi, Pakistan.

Weller, J.I. and Y. Folman. 1990. Effects of calf value and reproductive management on optimum days to first breeding. J. Dairy Sci. 73:1318-1326.

Wilde, C., A. Henderson and C. Knight. 1987. Effects of longterm thrice-daily milking on mammary enzyme activity, cell population and milk yield in the goat. J. Anim. Sci. 64:533-539.

Wilde, C., C. Addey, M. Casey, D. Blatchford and M. Peaker. 1988. Feedback inhibition of milk secretion: The effect of a fraction of goat milk on milk yield and composition. Q. J. Exp. Phys. 73:391-397. 